\title{
Brazilian Blogosfera Progressista: Digital Vanguards in Dark Times
}

\author{
Eleonora de Magalhães Carvalho*, Afonso de Albuquerque** and Marcelo \\ Alves dos Santos Jr***
}

*Pinheiro Guimarães College, Rio de Janeiro, Brazil, eleonoramaga@gmail.com , https://eleonoramagalhaes.wixsite.com/website

**Fluminense Federal University, Rio de Janeiro, Brazil, afonsoalbuquerque@id.uff.br

***Fluminense Federal University, Brazil, marcelo_alves@id.uff.br, www. marceloalves.org

Abstract: This article explores the Brazilian Blogosfera Progressista (Progressive Blogosphere, hereafter BP), a leftist political communication initiative aiming to conciliate an institutionalized model of organization with a networked model of action. Despite the disparity of resources existing between them, BP proved able to counter effectively the mainstream media's political framings, thanks to wise networking strategies, which explored the communicative opportunities offered by social media. The Centro de Estudos de Mídia Alternativa Barão de Itararé - Barão de Itararé Alternative Media Studies Center - is an essential piece in this schema, as it works as a coordinating agency for BP members and trains new participants. Our article intends to discuss this and other characteristics of BP as a group, and the challenges it faces at the present, after the rise of Jair Bolsonaro to Brazil's presidency.

Keywords: Blogosfera Progressista, counter-hegemonic media, activism, Brazil, Vanguard, networked organization

\section{Introduction}

In June 2013, massive demonstrations - known as the Jornadas de Junho (June Journeys) - took place in several cities in Brazil. The immediate factor triggering protests in the city of São Paulo was the rise of the bus fares, from 3,00 to 3,20 reais. Other demonstrations followed and, soon, they "were not only about the 20 centavos"; they also demanded better social services (as health and education), complained against the realization of the FIFA World Cup in 2014, and the Rio de Janeiro Olympic Games, in 2016, and denounced government corruption, among numerous other topics. They were hailed as a vibrant example of a new model of politics, one allowing the crowds to demonstrate (and even impose) their will to the political elites. Scholars soon identified parallels between these demonstrations and others occurring around the world, as the Occupy movement in the United States and Europe, the Indignados movement in Spain, the Arab Spring, among many others (Castells 2012). These movements were presented as a radically new type of political mobilization, capable of uniting different political agendas, a model that Bennett and Segerberg (2013) named "connective action", which was made possible by the emergence of social media.

In retrospect, it seems clear that the Jornadas de Junho backfired. When the demonstrations began, the Brazilian presidency was already in the hands of PT (Partido dos Trabalhadores, or Workers' Party) for ten years. During this period, consistent social 
policies led millions of people to ascent from poverty to a middle-class status, numerous public universities were created, and affirmative policies allowed for the first time a massive number of non-white people to have access to them. Additionally, the economy looked solid, and Brazil enjoyed a considerable prestige in the international arena. President Luis Inácio Lula da Silva ended his two-terms period (2003-2006 and 2007-2010) with a record high popularity, and just before Jornadas de Junho, his successor Dilma Rousseff was very popular too (Ballestrin 2019; Singer 2019). Ironically, most leaders of the first demonstration were members of PT, aiming to push the party more to the left. However, as they disdained the very idea of a political vanguard, they were incapable to coordinate actions in order to obtain practical results from the protests. Even worse, right-wing militants infiltrated the manifestations and, little by little, proved able to hijack their agenda, by changing the focus to corruption, and then to PT's corruption.

Additional manifestations occurred in 2014 - this time against the FIFA World Cup - and contributed to weaken PT and president Rousseff, who, despite this, managed to be re-elected. Protests asking Rousseff to be impeached began just after she was sworn in, in January 2015 - this time carried out by right wing groups and supported by the mainstream media, with basis on the allegation that PT was a "criminal organization". Under a strong attack both from the Judiciary - the Lava Jato Operation, led by Judge Sergio Moro, turned from a general anti-corruption crusade into an anti-PT movement - and the mainstream press, Rousseff was impeached in 2016, in a parliamentary coup. In 2018, Lula was arrested after a Kafkaesque judicial process, and prevented in disputing the presidential elections. Jair Bolsonaro, a far-right politician, won the elections and invited Moro to be his Minister of Justice (Feres Junior and Gagliardi 2019). In a short term, neoliberal policies reverted the previous social conquests, political repression peaked, the universities went under attack. Interestingly, the bus fare in São Paulo is now 4,30 reais.

The disdain regarding the importance of the political vanguards proved to be a core fragility for the Jornadas de Junho movement. Yet, despite the massive attention it received, this is not the only existing model that explores the potentialities of digital media for political mobilization. This article explores one of these alternatives: The Brazilian Blogosfera Progressista (Progressive Blogosphere, hereafter BP) a leftist political communication initiative aiming to conciliate an institutionalised model of organisation with a networked model of action. Despite the disparity of resources existing between them, BP proved able to counter effectively the mainstream media's political framings, thanks to wise networking strategies, which explored the communicative opportunities offered by social media. The Centro de Estudos de Mídia Alternativa Barão de Itararé - Barão de Itararé Alternative Media Studies Center - is an essential piece in this schema, as it works as a coordinating agency for BP members and trains new participants. Contrary to that suggested by Bennett, Segerberg and Castells, we contend that there is still room for collective models of activism and old principles characteristic from socialist activism - as the vanguard model of organization - remain valid nowadays, in a growingly digital environment.

The article is organized as follows. It starts with the origins of BP in light of two historical antecedents: 1) the influential role that communist professionals exerted in the process of modernization of the Brazilian journalism, in the 1950-70s; 2) the tradition of independent journalism, which developed in Brazil during the military dictatorship era, in the 1960-70s. The third section discusses the organisational characteristics of BP. It proposes a typology of its members, describes its networking structure and the vanguard role that Barão de Itararé Center performs on it. The fourth section 
focuses on BP modus operandi and its impact as a counter-hegemonic media. The fifth and sixth sections discuss, respectively, the challenges faced by BP after the 2016 coup, and the surprising opportunities that the chaotic Bolsonaro government present to the rebuilding of the Brazilian left. The final section looks for general lessons from the BP. It is argued that the logic of collective action remains as necessary as ever for social movements, and that models of organization originated from socialism - as the organizing role of political vanguards - are still necessary in order to allow them to establish and pursue coherent strategies and courses of action.

\section{Historical Context}

The origins of BP in Brazil can be traced to 2006, when political activists and journalists joined efforts in search of a counter-hegemonic alternative to the conservative mainstream media, one of the most concentrated in the world (Moreira 2016). After the return of democracy, in 1985, Brazilian mainstream media claimed to exert a quasi-official branch of the government, whose attributions included to act as a moderating power with respect to the three official branches of government, intervening in political issues "for the sake of democracy" (Albuquerque 2005; Guimarães and Amaral 1988). Concretely, this implied in systematically taking sides against the political left in general and PT in particular (Azevedo 2017; Feres Junior and Gagliardi 2019)), as well as, championing neoliberal policies as corresponding to the "national interest".

After Lula was sworn in as Brazil's president, in 2003, the mainstream media lost much of their ability to influence the government's political agenda, but still remained very powerful. In the following years, they used this power as a means to destabilize Lula and PT, by associating them to negative values as populism, corruption, and authoritarianism (Albuquerque 2019), but this was not enough to avoid Lula's reelection in 2006, and from making Dilma Rousseff his successor in 2010 - she was also reelected in 2014. As this happened, they engaged in a campaign aiming to defeat PT by any means (Damgaard 2018; Feres Junior and Sassara 2018). This finally worked, as President Rousseff was deposed in 2016, and Lula was put in jail in 2018 - in both cases after very controversial political and judicial processes.

It was against this backdrop that BP emerged as a counter-hegemonic medium. Still, other factors must be taken in account to understand BP's development in Brazil. A first aspect that influenced the progressive blogosphere in Brazil refers to particular characteristics of the development of Brazilian journalism and how it impacted on the journalists' professional culture. Two elements may be emphasized here: 1) the considerable influence that communists exerted in the Brazilian journalistic culture, in the decades following the end of World War II; 2) the rise of an independent journalism movement in the 1960-70s.

In the 1950-70s, there were many communists in Brazilian newspapers - even in conservative ones - some of them in editorial positions. The owners of these newspapers were aware of the presence of communists, but they did not matter - $O$ Globo's owner, Roberto Marinho used to refer to them as "my communists" (Albuquerque and Roxo da Silva 2009). This happened for different reasons. First, most Brazilian communists had a middle-class background, rather than a working-class one, and communism had a considerable appeal for a large part of Brazilian intelligentsia. This made them particularly attractive in a time when journalism experienced a modernisation process and needed a skilled workforce. Additionally, the Leninist views about the importance of the newspapers as an instrument for political organization contributed to make journalism more attractive for Brazilian communists (Serra 
2007). Yet, the presence of communists in the newsrooms has come with a price: They were expected to not engage in subversive activities and be acquiescent to the newspapers' editorial lines. In fact, the newspapers' owners considered them as being a particularly disciplined group of journalists. In exchange, they enjoyed some autonomy in everyday routines in the newsroom, which allowed them to hire fellow communists. Paradoxically, the Communist Party's structure worked as a factor reinforcing the discipline in the newsrooms. This non-orthodox pact made sense because Brazilian communists had a reformist, rather than revolutionary approach to politics, and were disposed to make alliances with sectors of the bourgeoisie (Albuquerque and Roxo da Silva 2009).

This arrangement endured until the end of the 1970s. At that time, in a context of growing competition, newspapers looked for a more professional management system, in which the communists were not necessary anymore (Albuquerque and Roxo da Silva 2009). Added to this, the Communist Party was not as influential as before, as the Workers' Party (PT) emerged as a political force disputing its hegemony in the Brazilian left. Different from the communists, petista journalists viewed the newspapers' owners as adversaries, as they imposed an "economic censorship" that prevented them to make "real journalism" (Smith 1997). The journalists' unions became particularly active in voicing an anti-capitalistic view of journalism, by demanding social control of the news (Roxo 2013).

A parallel development refers to the rise of a model of independent journalism in Brazil in the 1960s and 1970s (Kucinski 1991). At that time, Brazil experienced a brutal military dictatorship, which systematically repressed the freedom of expression and brutalised journalists (Kushnir 2004; Smith 1997). However, this did not prevent the mainstream media outlets to unambiguously support and being generously rewarded for this (Guimarães and Amaral 1988; Kushnir 2004). In such circumstances, many journalists came to believe that the only possible manner to exert their profession was outside the mainstream media, as independent journalists. Numerous independent outlets were created, but most of them were short-lived, as they fell victim to political repression and economic difficulties (Kucinski 1991). However, the independent journalism ideal remained influential in Brazilian journalism's culture, and together with the anti-capitalism agenda, it served as an inspiring source to the BP.

A second factor that influenced the progressive blogosphere in Brazil has to do with political changes associated with the rise of the political left to the presidency, not only in Brazil but also in other South American countries, such as Argentina, Bolivia, Chile, Ecuador, Paraguay, Peru, Uruguay, and Venezuela. Despite being very different in their political styles - some more populists, others more institutionalised; some closer to socialism and others to social democracy (Cameron 2009; Castañeda 2006; Lupien 2013) - those countries proved able to forge a regional alliance and a common Latin American identity. The Latin American elites reacted to it, by presenting leftist governments as putting democracy in jeopardy, sometimes picturing them as a part of a broader "Bolivariana" or "Chavista" conspiracy. Accordingly, they claimed for themselves the performance of the role of the political opposition that political parties were not able to exert (Farah 2010). As the political engagement of Brazilian media became more and more explicit, professional journalists felt compelled to take side against them and, in order to do this, they joined political activists to form BP.

The third and last prerequisite of BP is technological in nature: The new wave of independent journalism and political activism would not be possible in the absence of a media infrastructure allowing low-cost communication between activists, journalists 
and their public. The rise of blogs, in the early-2000s, and social media networks such as Facebook, Twitter and Instagram provided them with the means to present an alternative to the mainstream media - although, as Bailey and Marques (2012) observe, in many cases, originally independent journalistic blogs were absorbed by the mainstream media. Furthermore, the networking character of these media allowed activists and journalists to forge strategies permitting them to reach a much larger public that would be possible if they acted in an isolated manner.

\section{Structure}

$\mathrm{BP}$ is a complex organisation with porous borders. It includes agents with different (although essentially compatible) agendas, institutional profiles, and models of action. This section explores BP as a particular type of media ecosystem (Magalhães and Albuquerque 2017; Rovai 2018), describes the characteristics of the actors taking part in it, the types of relationship they have established with each other, and the role performed by Barão de Itararé as a vanguard agent, which provided BP with a considerable degree of organicity.

\subsection{Typology of BP Members}

The members of BP differ in their nature, status and social capital type (De Magalhães Carvalho 2018). As its origin coincides with the rise of the personal blogs (Aldé, Escobar and Chagas 2007; Quadros, Rosa and Vieira 2005), BP was initially a confederation of individuals but, since then, it has evolved and included other, more institutional types of agents. Individuals form the most important aspect of the BP ecosystem. Notable cases include Rodrigo Vianna's O Escrevinhador and Conceição Oliveira' Maria Frô. In some cases, individual blogs evolved to become small journalistic outlets, as Paulo Henrique Amorim's Conversa Afiada, which is run by four journalists. There are also more consolidated journalistic groups, such as Brasil 247, Opera Mundi, Revista Forum, all originally online, and the online version of the magazine Carta Capital, and other media related to political parties, such as the web portal Vermelho that is associated with the Communist Party of Brazil (Partido Comunista do Brasil, hereafter PCdoB), and PT na Câmara that is associated with PT (De Magalhães Carvalho 2018; Magalhães and Albuquerque 2017).

A BP membership is associated with different types of sources of authority. The three most relevant types are journalists, activists and politicians. Journalists have the more prestigious position in the BP ecosystem. Many of them had distinguished careers in the mainstream media before joining BP, and some were able to conciliate both activities (Guazina 2013). Conversa Afiada's Paulo Henrique Amorim worked for a long time as the anchor of Globo Network's newscast Jornal Nacional and Jornal da Globo and remained as the anchor of the Record Network until 2019, when he was fired. He eventually passed away a few weeks thereafter. Viomundo's Luis Carlos Azenha worked as a television reporter on the SBT, Manchete and Globo networks. Luis Nassif, from GGN Jornal, was a member of the Editorial Council of the newspaper Folha de S. Paulo. Paulo Nogueira, the editor of Diário do Centro do Mundo held editorial and foreign correspondent positions in Veja, Exame and Época. Socialista Morena's Cynara Menezes formerly worked for Folha de S. Paulo and the Veja magazine. The founding members of BP began their blogs as personal projects, parallel to their professional careers, according to the spirit of "personal blogs" of the mid-2000s, and posteriorly professionalised them (Guazina 2013). They sustain an ambiguous relationship with the mainstream media as, on the one hand, they contend they don't do real journalism, as they are compromised with economic and polit- 
ical interests but, on the other hand, their past work in these very media paradoxically provides them with journalistic authority (Zelizer 1992) which lends credibility to BP as a whole.

Different from journalists, whose foremost interest in BP lies on exerting journalism far from the imposed constrains by the mainstream media, activists perceive it as a means for promoting a political cause. Activists are much more diversified in their authorizing sources and styles than journalists. Conceição Oliveira, the head of the blog Maria Frô describes herself as a historian and educator who fights for racial and gender equality. Created as a strictly personal blog, Maria Frô subsequently acquired a more political tone. It later was hosted in the web portal Forum. Oliveira also cooperates with other BP media. Another prominent member of BP is Eduardo Guimarães, a lawyer who had no previous political experience before founding his Blog da Cidadania.

The boundaries between the identities of journalists and activists are considerably porous, however, as BP descends from the independent journalism movement. The case of Altamiro Borges - responsible for Blog do Miro, and one of the most important articulators of Barão de Itararé - is a case in point in this respect. He graduated in journalism studies in 1979, the same year he became affiliated to PCdoB. Since since then he has engaged in the midialivrismo (free media) movement and has been allied with other social movements such as the MST (Movimento dos Trabalhadores Rurais Sem Terra, Movement of Landless Rural Workers). The blending between the journalist and activist identities is particularly notable in some of the more institutionalised actors of B such as Revista Forum, Carta Maior and Brasil de Fato, as their origins are related to the World Social Forum, an anti-neoliberal globalisation event whose first edition occurred in the city of Porto Alegre in 2001 (De Magalhães Carvalho 2018).

The third category, politicians, refers to individuals who had a political career before joining BP, political parties and other political organisations. Two parties PCdoB and PT - have been particularly active in BP. PCdoB was a junior partner during the PT-led governments, but in BP their asymmetrical relationship was somewhat inverted. PCdoB benefited from its large experience in communication in accordance with Leninist principles. When it split from PCB (Partido Comunista Brasileiro/Brazilian Communist Party) in 1962, PCdoB inherited the newspaper Causa Operária (Worker's Cause), which was deemed illegal during the military dictatorship (1964-1985). In 2002, PCdoB was a pioneer in using digital media as a resource for party communication, as it created the web portal Vermelho (Red). Causa Operária and Vermelho adopted totally different communicative logics: While Causa Operária targeted hardcore activists, in a time when they faced intense political repression, and used a very politicised language, Vermelho looked to reach a broader public through a more informative approach, which is expressed by the slogan "the wellinformed left" (Mourão 2009).

\subsection{BP's Networking Structure}

More than a group of individuals, BP is also defined by the concrete relations the individuals involved in it establish with each other. Working as a pack, BP is a force to be respected. It works through a verticalised network structure, which is built through reciprocal quoting, sharing of posts, linking to other members' pages and "official" policies of partnership, which are indicated in the blogs' blogrolls. This allows the messages originally posted by particular members to reach a much larger audience 
than it would be possible otherwise. A network schema of the relations between BP members' Facebook pages can be found in Figure 1.

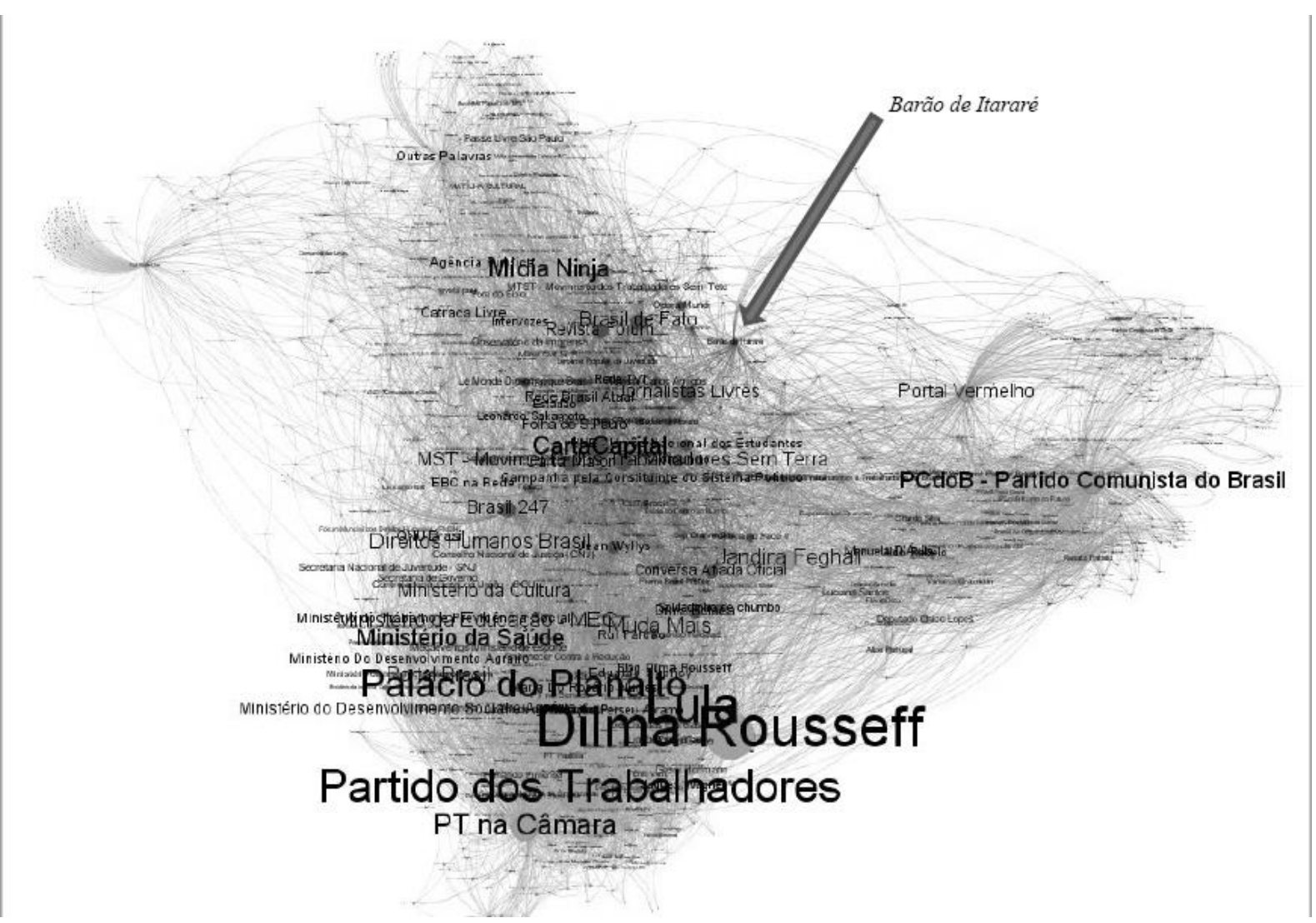

Figure 1: BP Network in Facebook

This logic results in a hierarchical model of organisation. The central position in the system is occupied by prestigious journalists and activists, in most cases belonging to BP's first generation (Magalhães and Albuquerque 2017). Their prestige allows their posts to be shared with a wider range of people than others. The second level refers to other actors identifying themselves as members of BP. Many of them joined BP later and do not use blogs but have social media accounts on Twitter, Facebook, Instagram and other platorms that they use to echo BP's content.

The third level refers to agents that do not belong formally to the BP universe, but establish some tactical alliances with it, motivated by common interests or sensibilities. A particularly relevant case refers to other leftist activist media organisations that differ from BP in their political and organisational approaches. Two particularly relevant cases refer to Mídia Ninja and Intercept Brasil. Mídia Ninja - Ninja is an acronym for Narrativas Independentes, Jornalismo e Ação (Independent Narratives Journalism and Action) - is a collaborative journalism project providing live coverage of protests through the use of cell phones, which gained momentum during the Jornadas de Junho in 201 when activists in their coverage provided live testimonies of police brutality (Cammaerts and Jiménez-Martinez 2014; Penteado and Souza 2016). Initially, BP actors were mostly suspicious both of Mídia Ninja's unmediated journalistic methods and its political agenda, as they were sceptical or even critical of the Jornadas de Junho's political intentions and impact. However, BP and Mídia Ninja established closer ties after 2016, when they allied in defence of President 
Rousseff's government, which faced a process of impeachment. In the same line, The Intercept Brasil, the Brazilian branch of The Intercept - which played a central role in the Wikileaks case - gained a lot of prestige among BP members in consequence of the Vaza Jato initiative, which presented disturbing evidences about the political motivations behind Lava Jato and pointed to the operation as an effort for toppling President Rousseff and putting former President Lula in jail.

\subsection{The Role of Barão de Itararé as BP's Political Vanguard}

Online networking practices have a great importance in forging BP as a coherent political media group, but offline models of organisation are also essential. Barão de Itararé has a crucial role in institutionalising BP. The origins of Barão de Itararé can be traced to the Confecom (Conferência Nacional de Comunicação or National Conference of Communication), in 2009 (Rovai 2018). At that time, the Brazilian government called representatives of diverse civil-society organisations to discuss the model of media communication existing in Brazil, and proposing modifications to it (Intervozes 2010). A similar approach was adopted later with respect to the Marco Civil da Internet in 2014. Many proposals resulted from the meeting, as for instance: the acknowledgement of communication as a social right; the creation of a National Communications Council, which would be responsible for establishing and monitoring public policies on the sector; public funding policies for the media and measures intending to avoid property concentration. These proposals alarmed the mainstream media organisations, which accused Confecom of trying to establish a potentially authoritarian model of control of communications. Contrary to what was happening with the Marco Civil, the measures proposed by Confecom were not approved by the Brazilian National Congress. Nevertheless, Confecom was the seed of BP, thanks to the Barão de Itararé's efforts.

The Barão of Itararé Center was created in May 2010 with the purpose of "creating something capable of reuniting social movement activists with journalists and bloggers who took part in Confecom" (Borges 2016). In August, it promoted the First National BlogProg Meeting in São Paulo. Other meetings followed in 2011 (Brasília), 2012 (Salvador), 2014 (São Paulo), 2016 (Belo Horizonte). Additionally, Barão de Itararé promoted other events, such as an international meeting in 2011. In 2013, it sponsored the first edition of the National Course of Communications for Media Activists, targeting activists from community, unions and alternative media.

According to its president Altamiro Borges, Barão de Itararé has four core objectives: 1) to take part in the fight for the democratisation of the Brazilian media; 2) the support of alternative media in Brazil; 3) the study of the transformations happening in the media landscape at the present; 4) the education of new communication activists. In order to do this, Barão de Itararé conciliates a rigid hierarchical structure, which include a President, a General Secretary, different Directors, a Fiscal Council and an Advisory Council with a considerable diversity in its membership, including intellectuals from different leftist groups. As Penteado and Souza put it, it "presents a transitional model between the traditional one and those exclusively based online, as it sustains a verticalized structure and actors associated to it preserve their autonomy to act and produce content" (2016, 47-48). These characteristics constitute Barão de Itararé's role of a political vanguard role in BP. Although activists associated with PCdoB have a particularly prominent role in Barão de Itararé, their influence on the BP agenda is quite limited. PCdoB is not a significant player in national politics, and therefore its political ambitions are modest. This allows other agents to feel comfort- 
able with Barão de Itararé's role. Paulo Henrique Amorim, whose core source of authority is associated with journalism, provides an example:

I am sympathetic to the Instituto de Mídia Alternativa Barão de Itararé, which tries to gather giant egos around punctual missions. But his president Miro Borges often succeeds. The movement's results are stronger than the sum of progressive bloggers. They have a role that I think is formidable: to disseminate the poison that, in the end, contaminates the dominant system (Amorim 2017).

\section{Modus Operandi and Impact}

Putting it simple, BP provides the basis for a critical counter-public - that is a counterhegemonic public sphere (Fuchs 2010; Negt and Kluge 1993) - aiming to challenge the views disseminated by the mainstream media. As BP is not only a vehicle, but a media ecosystem (Magalhães and Albuquerque 2017; Rovai 2018), the activities of its members include not only producing and divulgating media content, but also sharing material produced by fellow members, or other critical content. In most cases, the material vehiculated by BP consist of pieces critical to the mainstream media news coverage, as well as interviews and analytical pieces, and more rarely, in-depth reporting.

A concrete example, referring to the Bolinhagate incident, illustrates the dynamics of BP collaboration in opposing mainstream news media framings. In the morning of October 20, 2010, just a few days before the presidential elections - in which PT's Dilma Rousseff appeared as a clear favourite - José Serra, the main candidate opposing PT's government was hit by an object on his head, during a campaign walking tour in Rio de Janeiro. The walking tour was then cancelled, and Serra was taken to a hospital. The scene was registered by a Folha de $S$. Paulo reporter with a cell phone camera, and at night, it was exhibited by Jornal Nacional, Rede Globo's main newscast, in a two and half minutes news piece that described the object as being solid, and therefore the situation as an attempt against Serra, made by PT activists. In the following day, Jornal Nacional dedicated seven minutes to the incident, presenting a non-official report made by the forensic expert Ricardo Molina. Other mainstream news media, such as the newspapers Folha de S. Paulo, O Estado de São Paulo and Veja magazine, echoed the idea that Serra had been hit by a solid object.

Then, Daniel Florêncio, a film maker, posted on Twitter a video entitled "Bolinhagate - the Jornal Nacional edition", which denounced the mainstream media's coverage as a fabrication. According to him, Serra was hit by a paper ball (bolinha de papel in Portuguese), and not a solid object (in fact, posterior images did not show any bruises on Serra's head, and this is significant, as he is bald). The video was retweeted by Cynara Menezes and other influent bloggers and then went viral. Viomundo published a letter, written by the Federal Forensic Experts Association, raising doubts about the mainstream version of the incident. Other important BP vehicles shared the letter. Rodrigo Vianna published on his blog $O$ Escrevinhador that some journalists from the Globo Network became so ashamed of the Jornal Nacional's seven-minutes news segment that they booed when it aired.

Humour was another resource employed to spread the message. Serra was portrayed as the Matrix's character Neo, dodging a paper ball. A picture showed a paper ball with the X-Files title "I want to believe" behind it. Activists even created a flash game, which invited players to throw paper balls at Serra, as he tried to hide behind 
the Jornal Nacional's bench. BP's version reverberated in the international media and hashtags related to the case became trend topics on Twitter.

The Bolinhagate case presents a vivid example of how a collective effort made by BP members allowed them to successfully counter mainstream media framings. BP members made intensive use of social networking sites to propagate their narratives. Comparative analysis shows that Brasil 247, one of the most prominent progressive bloggers, managed to gather more visibility than some traditional media organisations.

Time-series of the total shares of publications on Facebook reveals that the Brasil 247 fan page reached 16 million shares on 2016, the year of Dilma Rousseff's ousting by the Brazilian Parliament. In comparison, $O$ Globo, one of the largest newspapers in the country, shows an opposite trend of decay after 2014. Results shed light on BP's struggle for online visibility, as Progressive bloggers were able to amass more shares than resourceful media organizations.

\section{The Challenges ahead of BP}

Having been created during the PT-governments era, BP has been facing unprecedented challenges in recent years. During the second term of Dilma Rousseff's presidency, PT politicians and its allies became subject to a continuous harassment by the judiciary, public prosecutors, the press, and far-right activists. Things became worse when vice-president Michel Temer took Rousseff's place after her impeachment. In order to avoid PT's return to power, former president Lula - who was the favourite in all electoral polls to win the presidential race - was arrested. The Brazilian Supreme Court prohibited that Lula gave interviews to the press under the allegation that this could "disturb" the electoral process. Additionally, during the entire campaign the mainstream media presented Fernando Haddad, who replaced Lula as PT's candidate, as being a political extremist who is just as dangerous to democracy as Jair Bolsonaro (Feres Junior and Gagliardi 2019).

The Brazilian mainstream media has traditionally refused to recognise BP members as legitimate media agents, as they claim for themselves the monopoly of the right of doing genuine journalism. To be sure, their monopolist demands are so extensive that, in October 2016, the Associação Nacional de Jornais (National Newspapers Association or ANJ) required that the Brazilian Supreme Court limits the activities of the Brazilian branches of foreign online journalism outlets - as, for instance, $B B C$ Brasil and El País Brasil - under the allegation that they violate a Constitutional limit that establishes a 30-percent limit of foreign participation in Brazilian media organizations (Folha de S. Paulo 2016). Mainstream media play an even rougher role in the fight against their BP competitors, which they call "dirty blogs" and to whom they deny a journalistic status, despite the fact that in many cases bloggers previously had a solid career in the mainstream media.

The consequences of this can be very serious, as illustrated by the case of Blog da Cidadania's Eduardo Guimarães. In March 2017, he was detained by the Federal Police under the orders of Judge Moro, who accused his blog of being a "vehicle of political propaganda" and releasing confidential information that put at risk the Lava Jato's investigations. According to Moro, as Guimarães was not a journalist, he had no right to the legal protection offered to journalists. More recently, in 2019, Glenn Greenwald, the Pulitzer Prize winner ahead of the Intercept Brasil was portrayed by part of the mainstream media as being a hacker, rather than a journalist, in an attempt to demoralize the Vaza Jato series, presenting it in a criminal framing. 
A second challenge is the emergence of a highly popular alt-right media ecosystem. In the events leading to the parliamentary coup against Dilma Rousseff, strong machines of far-right propaganda disputed the narratives and discourse both from the traditional journalism vehicles and from progressive bloggers. The far-right ecosystem is a loosely connected network of diverse actors, ranging from journalists fired from the national press, authoritarian politicians, neo-Pentecostal preachers, digital savvy youngsters, and a myriad of parody/fake accounts (Santos Junior 2019). The far-right groups' model of operation differs from BP particularly considering the antisystemic hostility against parties, as well as the political, journalistic and intellectual establishment (Sponholz and Christofoletti 2019). The communication practices resemble astroturfing and informational warfare techniques such as the public harassment of opposition leaders, physical threats; all sorts of innuendo and smear campaigns (Santos Junior 2019).

Finally, a more recent development refers to the moral panic that has been generated, in a worldwide scale, around fake news (Carlson 2018), which gained ground in 2016, after the referendum that decided for the United Kingdom's exit from the European Union (Brexit) and the election of Donald Trump as the President of the United States. In both cases, "Russian meddling" was blamed as one of the key factors explaining these electoral results (Boyd-Barrett 2019). The fake news problem gained a lot of attention in March 2018, when it was revealed that Cambridge Analytica, a political strategy company that worked for Trump, irregularly obtained data from more than 50 million Facebook users, and Facebook did nothing to prevent this surveillance.

This scandal contributed to aggravate already existing accusations against social media platforms as being co-responsible for the fake news wave. Reacting to these critiques, social media platforms engaged in a series of practices that, arguably, aimed to contain fake news diffusion. In Brazil, Facebook Journalism Project and Google News Initiative provided financial backing for Projeto Comprova (Comprova Project), an initiative joining three fact-checking agencies (Lupa, Truco and Aos Fatos) and news media outlets - some of them belonging to the mainstream media, as Veja, Folha de S. Paulo and O Estado de São Paulo (Strano 2018). Added to this, Facebook endowed Lupa and Aos Fatos with the responsibility of checking the distribution of fake news in its platform (Facebook 2018). Perpetrators would be eventually punished with a temporary or even permanent ban. Although fake news has been often associated with the far-right alt-media, the new censorship dynamics established by Facebook and the fact-checking agencies allowed them also to target BP members. For instance, on June 12, 2018, Revista Forum published the information that Pope Francis sent a chaplet and a letter to Lula, in order to express his solidarity to him. Although there were controversies with respect to details of the incident, Lupa promptly classified this news as fake news and as a consequence Revista Forum was subject to retaliatory measures, which included a temporary Facebook ban.

\section{Bolsonaro's Government and the Unexpected Opportunities for BP}

At a first sight, the rise of Jair Bolsonaro - an unabashed defender of the previous Brazilian military regime, who once said he intended to shoot leftist activists - to the Brazilian presidency seems to put BP in great peril. Surprisingly, this appears to not be the case. Bolsonaro's far-right activists do not identify BP as their prime adversary. Instead, they have focused their attention on the mainstream media, which they accuse to be "leftist" and "petista". Although some leftists have been targeted by Bolsonaro activists' harassment - The Intercept Brasil, in particular - this happened in a 
much less systematic manner than it would be expected. Indeed, it is possible to argue that Bolsonaro's disastrous and divisive style of government provides BP with promising political opportunities.

In order to understand that, it is necessary to highlight the very special circumstances allowing the 2016 coup against President Rousseff to happen. This was only possible because different fractions of the Brazilian political right joined forces with the mainstream media, leading sectors of the judiciary and the Prosecutor's Office, the Federal Police and military leaders to topple PT by any means (Albuquerque 2019; Tatagiba 2018). By blaming PT as the source of all corruption existing in Brazil, they succeeded in presenting the Brazilian left in a criminal framing and contended that the solution for the Brazil's political problems was to be achieved by judicial means. Judge Sergio Moro emerged, in their discourse, as the leader of a moral crusade, and the main antagonist of Lula, who was pictured as the mastermind of the enormous corruption schema that, allegedly, was led by PT (Damgaard 2018; Feres Junior and Gagliardi 2019). The far-right activists associated with Bolsonaro had a subsidiary role in this arrangement, as they were responsible for assembling people for the anti-PT manifestations and physically intimidating the leftists (Santos Junior 2019; Tatagiba 2018), who the press, conveniently, ignored.

Contrary to Rousseff, vice-president Temer, who took her place, had several accusations of corruption pending against him. In his government, several social policies established by the PT-led governments were reverted, the economy stalled, and the confidence in the institutions of representative government collapsed (Goldstein 2019). In 2018, Lula emerged as the clear favorite to win the elections, but he was put in jail on the orders of Judge Sergio Moro. Contrary to the mainstream elites' expectancies, however, this did not benefit the institutional right. Rather, the crisis of legitimacy of the representative institutions, which resulted from the Lava Jato Operation, opened the way for the antisystem candidate Jair Bolsonaro. He disputed the second round of the election with Fernando Haddad, a candidate with a political moderate profile, who was the former mayor of the city of São Paulo and succeeded Lula as the PT candidate. Although the mainstream media were not sympathetic to Bolsonaro, they actually preferred him to Haddad, who was presented as being as dangerous to democracy as Bolsonaro - but worse than him, because he supposedly was a radical leftist (O Estado de São Paulo 2018).

The rise of Bolsonaro to the presidency proved to be disastrous for the unity of the Brazilian right. Even though the mainstream media and rightist forces support Bolsonaro's neoliberal reforms, his outrageous style of government, poor economic indexes and pathetic performance in international forums (as in his inaugural discourse in the UN General Assembly), blatant nepotism (illustrated by his attempt to nominate his son Eduardo Bolsonaro as Brazilian Ambassador to the United States), and, last but not least, reports about his family connections with criminal organisations (UO 2019) have raised a severe criticism among the mainstream press - although nothing comparable to the treatment they gave to Lula or PT. In his turn, in many occasions Bolsonaro complained about the mainstream media coverage of his government - for instance, he threatened to stop giving interviews unless they "tell the truth" about his discourse at the UN - and even suggested he could take measures to economically constrain some media. Bolsonaro also has maintained conflictual relations with the Brazilian Congress, Supreme Court, and even his own political party. The popularity of the president plummeted. He has been rated as the worst first term president so far, and even some of his far-right supporters now abrogate him. 
The institutional crisis is not limited to Bolsonaro's government, however. When, Sergio Moro accepted his invitation to be the Minister of Justice, the credibility of the Lava Jato Operation suffered a major blow, as his impartiality became highly questionable. Although part of the mainstream media initially presented him as the "rational", "institutional" face of the government, his prestige was damaged by Bolsonaro's numerous scandals and public acts to demote him. Even worse, the Vaza Jato series a major investigative report led by the renowned journalist Glenn Greenwald on leaked Telegram chats among task force members - indicated that the process that led to Lula's imprisonment was a judicial farce, as the Judge and the prosecutors articulated their actions not only with each other, but also with the mainstream media, in an effort to de-moralise Lula and PT. Indeed, Folha de S. Paulo's newspaper present self-criticism regarding its coverage of Lava Jato (Lima 2019). At the present, the Brazilian judiciary is deeply divided at all levels. In sum, Brazil currently experiences an extraordinarily serious institutional crisis in all branches of government.

As serious as the Brazilian current situation may be, from the perspective of the Left and BP in particular, it represents a political opportunity. Once formidable, the forces that overthrew Dilma Rousseff from the presidency and put Lula in jail are now divided and have spent a lot of energy fighting each other. At the same time, mounting public evidences indicate that Lula's image as the mastermind of corruption in Brazil was a fabrication with political purposes. This, together with the dignity shown by Lula in jail - he refused to make any deal with the Justice Department - and the huge contrast between the achievements of his government and the disasters that followed the 2016 coup provide a fertile ground for the re-organisation of the left in Brazil. At a time when the adversaries are divided, the ability of BP to work as a political communication vanguard makes it a very relevant instrument to unify the discourse of the left around a common rhetoric and cause.

\section{BP in Perspective: The Role of Vanguard in Networked Media Activism}

In the 2010s, a new orthodoxy emerged regarding mediated social activism, having in the works of Castells (2012) and Bennett and Segerberg (2013) their main exponents. Based on protests occurring in different parts of the world - Tunisia, Iceland, Spain, United States, Iran, among many other examples - they suggested that the Internet offered brand new opportunities for political mobilisation, as it allowed people to connect to each other beyond the limits of physical space. According to Castells, the digital media allow individuals to recognise common problems and, then, by joining forces and occupying public spaces, to challenge the established powers. As these movements originate in the emotions of individuals, shared through networked cognitive empathy, they "are the less hierarchical in their organization and the more participatory in the movement" (Castells 2012, 15).

In a similar vein, Bennett and Segerberg identify these movements as organised on the basis of a digitally networked connective action model, which differs from the traditional collective action model, as it is neither structured in reference to an organising centre nor does it have a hierarchical structure. Rather, such movements are based on the phenomenon of personalised politic that features "citizens seeking more flexible association with causes, ideas, and political organizations" (Bennett and Segerberg 2013,5$)$. In both cases, the idea that vanguards are an indispensable part of political movements seem to be an anathema.

Yet, as impressive as these movements seemed to be at a first glance, their capacity to produce concrete results in the mid-term proved to be questionable at best, as they were not able to secure sustainable changes and, worse, in many countries 
governments actually turned to the right or even, as in Brazil, to the far-right. As Gerbaudo (2013a; 2013b) observed, in reference to Egypt, the organisational fragility of the prodemocracy movement, closely associated to the informal character of mobilisation and the model of leaderless resistance, not only prevented them to reach their goals but, indeed, resulted in a military coup that launched the country again into a full dictatorial state. This suggests that, contrary to the hopes of Castells and Bennett/Seberberg, vanguards may still be necessary to convert revolutionary situations into revolutionary outcomes (Tilly 1978).

Contrary to the dominant view, this article argues, with basis on the example of $\mathrm{BP}$, that there is still room for the collective action in networked movements, and old models of organisation, associated to the socialist movements - as the role of the political vanguards - remain relevant in the digital era. As tempting as the ideals of "personalisation" and "participation" may be, they don't provide a solid basis for coherent collective movements (Fenton and Barassi 2011; Fuchs 2010). However, the concrete manners to instrumentalise political vanguards are not obvious, as the present social and technological circumstances differ sharply from those existing when the notion of political vanguard was coined (Pimlott 2015). For this reason, it can be instructive to analyse concrete initiatives based on the political vanguard principle as, for instance, BP. More than simply an alternative, BP is a critical media initiative (Fuchs 2010), which combines a networked model of action (through hyperlinks and content sharing) with centralised principles of organisation (Barão de Itararé Center is a central piece in this arrangement). BP also preserves some personalised traits not a surprise given its origins lie in personal blogs - which help to provide it with a considerable capillarity, but, at the same time, it is a considerably institutionalised environment, in which traditional institutions as political parties, social movements and journalism exert a core organising role. Until today, this model of organisation allows BP to work as an effective critical media environment. However, BP's dependence on social media may be a factor of risk to its survival, as they, allied to the mainstream media and fact-checking agencies, have employed the rhetoric of combating fake news as a tool for curbing political dissidence.

\section{References}

Albuquerque, Afonso de. 2019. Protecting Democracy or Conspiring Against It? Media and Politics in Latin America: A Glimpse from Brazil. Journalism 20 (7): 906-923.

Albuquerque, Afonso de. 2005. Another 'Fourth Branch' Press and Political Culture in Brazil. Journalism 6 (4): 486-504.

Albuquerque, Afonso de and Marco Antonio Roxo da Silva. 2009. Skilled, Loyal, and Disciplined: Communist Journalists and the Adaptation of the Model of the American Model of "Independent Journalism" in Brazil. The International Journal of Press/Politics 14 (3): 376395

Aldé, Alessandra, Juliana Escobar and Viktor Chagas. 2007. A febre dos blogs de política. Revista Famecos 14 (33): 29-40.

Amorim, Paulo Henrique. 2017. Blogueiros Progressistas - Conversa Afiada. Interview by Eleonora de Magalhães Carvalho. January 9.

Azevedo, Fernando Antônio. 2017. A grande imprensa e o PT (1989-2014). São Carlos: Edufscar.

Bailey, Olga Guedes and Francisco Paulo Jamil Marques. 2012. Brazilian News Blogs and Mainstream News Organizations: Tensions, Symbiosis or Independency. In The Handbook of Global Online Journalism, edited by Eugenia Siapera and Andreas Veglis, 395411. Malden, MA: Wiley-Blackwell. 
Ballestrin, Luciana Maria de Aragão. 2019. Post-Democracy and Neoliberalism in Contemporary Latin America: The Rise of the Left Turns and the Brazilian Democratic Failure. In The Brazilian Left in the $21^{\text {st }}$ Century: Conflict and Conciliation in Peripheral Capitalism, edited by Vladimir Puzone and Luis Felipe Miguel, 259-293. London: Palgrave Macmillan.

Bennett, W. Lance and Alexandra Segerberg. 2013. The Logic of Connective Action: Digital Media and the Personalization of Contentious Politics. Cambridge: Cambridge University Press.

Borges, Altamiro. 2016. Blogueiros Progressistas - Blog do Miro. Interview by Eleonora de Magalhães Carvalho. November 3, 2016. Audio transcription.

Boyd-Barrett, Oliver. 2019. Fake News and 'RussiaGate' Discourses. Propaganda in the Post-Truth Era. Journalism 20 (1): 87-91.

Cameron, Maxwell A. 2009. Latin America's Left Turns: Beyond Good and Bad. Third World Quarterly 2 (30): 331-348.

Cammaerts, Bart and Cesar Jiménez Martinez. 2014. The Mediation of Brazilian V-forVinegar Protests: From Bilification to Legitimation and Back? Liink em Revista 10 (1): 4468.

Carlson, Matt. 2018. Fake News as an Informational Moral Panic: The Symbolic Deviance of Social Media During the 2016 Presidential Dlection. Information, Communication \& Society. https://www.tandfonline.com/doi/full/10.1080/1369118X.2018.1505934

Castañeda, Jorge. 2006. Latin America's Left Turn. Foreign Affairs 3 (85): 28-43.

Castells, Manuel. 2012. Networks of Outrage and Hope. Social Movements in the Age of Internet. Cambridge: Polity Press.

Damgaard, Mads Bjelke. 2018. Media Leaks and Corruption in Brazil. The Infostorm of Impeachment and the Lava Jato Scandal. New York: Routledge.

De Magalhães Carvalho, Eleonora. 2018. Jornalistas empreendedores: o segmento progressista como nicho de mercado na web. Aurora. Revista de Arte, Mídia e Política 11 (32): 110-127.

Facebook. 2018. Facebook lança produto de verificação de notícias no Brasil em parceria com Aos Fatos e Agência Lupa. Newsroom, May 10. Accessed July 10, 2019. https://br.newsroom.fb.com/news/2018/05/facebook-lanca-produto-de-verificacao-denoticias-no-brasil-em-parceria-com-aos-fatos-e-agencia-lupa/

Farah, Tatiana. 2010. Entidades de Imprensa e Fecomércio estudam ir ao STF contra plano de direitos humanos. O Globo, March 18. Accessed April 02, 2016.

https://oglobo.globo.com/politica/entidades-de-imprensa-fecomercio-estudam-ir-ao-stfcontra-plano-de-direitos-humanos-3037045\#ixzz2HndMBDbY

Fenton, Natalie and Veronica Barassi. 2011. Alternative Media and Social Networking Sites: The Politics of Individuation of and Political Participation. The Communication Review 14 (3): 179-196.

Feres Junior, João and Juliana Gagliardi. 2019. O antipetismo da imprensa e a gênese da nova direita. In Brasil em colapso, edited by Esther Gallego, 25-43. São Paulo: Editora Unifesp.

Feres Junior, João and Luna de Oliveira Sassara. 2018. Failed Honeymoon: Dilma Rousseff's Third Election Round. Latin American Perspectives 45 (3): 224-235.

Folha de S. Paulo. 2016. ANJ vai ao Supremo para que sites respeitem limites ao capital estrangeiro. Accessed January 21, 2018. https://www1.folha.uol.com.br/mercado/2016/10/1827214-anj-vai-ao-supremo-para-quesites-respeitem-limite-ao-capital-estrangeiro.shtml

Fuchs, Christian. 2010. Alternative Media as Critical Media. European Journal of Social Theory $13(2): 173-192$.

Gerbaudo, Paolo. 2013a. The Impermanent Revolution: The Organizational Fragility of the Egyptian Prodemocracy Movement in the Troubled Transition. Social Justice 39 (1): 8-23.

Gerbaudo, Paolo. 2013b. The roots of the coup. Soundings 54: 104-113. 
Goldstein, Ariel Alejandro. 2019. The New Far-Right in Brazil and the Construction of a Right-Wing Order. Latin American Perspectives 46 (4): 245-262.

Guazina, Liziane. 2013. Jornalismo que tem lado: o caso dos blogueiros brasileiros "progressistas". Brazilian journalism research 9 (2): 68-87.

Guimarães, César and Roberto Amaral. 1988. Brazilian Television: A Rapid Conversion to the New Order. In Media and Politics in Latin America: The Struggle for Democracy, edited by Elizabeth Fox, 125-137. London: Sage.

Intervozes. 2010. Conferência Nacional de Comunicação: Um marco para a democracia brasileira. Accessed June 8, 2017. http://intervozes.org.br/conferencia-nacional-decomunicacao-um-marco-para-a-democracia-no-brasil/

Kucinski, Bernardo. 1991. Jornalistas e revolucionários: nos tempos da imprensa alternativa. São Paulo: Editora Página Aberta.

Kushnir, Beatriz. 2004. Cães de guarda: jornalistas e censores, do Al-5 à Constituição de 1988. São Paulo: Boitempo Editorial

Lima, Flavia. 2019. A Folha faz autocrítica. Jornal reflete sobre manchetes produzidas a partir de delações premiadas. Folha de S. Paulo. Accessed on October 8, 2019. https://www1.folha.uol.com.br/colunas/flavia-lima-ombudsman/2019/10/a-folha-fazautocritica.shtml

Lupien, Pascal. 2013. The Media in Venezuela and Bolivia: Attacking the "Bad Left" from Bellow. Latin American Perspectives 3 (40): 226-246.

Magalhães, Eleonora and Afonso de Albuquerque. 2017. A Blogosfera Progressista e a releitura do modelo de jornalismo independente no Brasil. In Comunicação e Cidadania Política, edited by Carlos José Napolitano, Maximiliano Martín Vicente and Murilo César Soares, 305-323. São Paulo: Cultura Acadêmica.

Moreira, Sônia Virginia. 2016. Brazil. In Who Owns the World's Media. Media Concentration and Ownership around the World, edited by Eli M Noam, 606-640. Oxford: Oxford University Press.

Mourão, Mônica. 2009. A esquerda bem informada. In $18^{\text {th }}$ Meeting of Compós, 1-20. Belo Horizonte: Compós.

Negt, Oskar and Alexander Kluge, 1993. Public Sphere and Experience. Toward an Analysis of Bourgeois and Proletarian Public Sphere. Minneapolis: The University of Minnesota Press.

O Estado de São Paulo. 2018. Uma escolha muito difícil. Accessed October 9, 2019. https://opiniao.estadao.com.br/noticias/geral,uma-escolha-muito-dificil,70002538118

Penteado, Claudio Luis de Camargo and Paulo Roberto Elias Souza. 2016. Jornalismo alternativo online e militância política: os casos Mídia Ninja e Barão de Itararé. Comunicaçao e Mercado 5: 37-52.

Pimlott, Herbert. 2015. Vanguard Media: The Promise of Strategic Communication? In The Routledge Companion to Alternative and Community Media, edited by Chris Atton, 32-42, London: Routledge.

Quadros, Claudia, Ana Paula Rosa and Josiany Vieira. 2005. Blogs e as transformações do jornalismo. E-Compós 3 (1): 1-21.

Rovai, Renato. 2018. Um novo ecossistema midiático: a história do jornalismo digital no Brasil. Buenos Aires: CLACSO.

Roxo, Marco. 2013. Companheiros em luta: a greve dos jornalistas de 1979. Niterói: Editora da UFF.

Santos Junior, Marcelo Alves. 2019. \#VaipraCuba: a gênese das redes de direita no Facebook. Curitiba: Appris.

Serra, Sônia. 2007. Jornalismo político dos comunistas no Brasil. Diretrizes e experiências da "Imprensa Popular". In 2nd Congresso of Brazilian Researchers in Political Communication, Belo Horizonte: Compolítica. 
Singer, André. 2019. From a Rooseveltian Dream to the Nightmare of Parliamentary Coup. In The Brazilian Left in the $21^{\text {st }}$ Century: Conflict and Conciliation in Peripheral Capitalism, edited by Vladimir Puzone and Luis Felipe Miguel, 45-67. London: Palgrave Macmillan.

Smith, Anne-Marie. 1997. A Forced Agreement: Press Acquiescence to Censorship in Brazil. Pittsburgh, PA : University of Pittsburgh Press.

Sponholz, Liriam and Rogério Christofoletti. 2019. From preachers to comedians: ideal types of hate speakers in Brazil. Global Media and Communication 15 (1): 67-84.

Strano, Salvador. 2018. Projeto Comprova reúne 24 veículos contra fake news. Meio \& Mensagem, 29 June. Accessed May 25, 2019. https://www.meioemensagem.com.br/home/midia/2018/06/29/projeto-comprova-reune-24veiculos-contra-fake-news.html

Tatagiba, Luciana. 2018. Entre as ruas e as instituições: os protestos e o impeachment de Dilma Rousseff. Lusotopie 17: 112-135

Tilly, Charles. 1978. From Mobilization to Revolution. New York: Random House.

UOL. 2019. Irmã de milicianos assinava cheques em nome de Flávio Bolsonaro, diz IstoÉ. Accessed October 10, 2019. https://noticias.uol.com.br/ultimas-noticias/agenciaestado/2019/02/22/irma-de-milicianos-assinava-cheques-em-nome-de-flavio-bolsonarodiz-isto-e.htm?fbclid=IwAR0E7KNyb3uLHFWdLJSTC52ugZG0m7FCTkja5CYQGbFMYUuEfAktv-BQqU

Zelizer, Barbie. 1992. Covering the Body: the Kennedy Assassination, the Media and the Shaping of Collective Memory. Chicago: University of Chicago Press.

\section{About the Authors}

Eleonora de Magalhães Carvalho

Eleonora de Magalhães Carvalho holds a $\mathrm{PhD}$ and $\mathrm{MA}$ in Communication from the Fluminense Federal University (UFF). She is professor in Journalism Department at Pinheiro Guimarães College (FPG) and conducts research and consulting in Political Communication and Digital Marketing.

\section{Afonso Albuquerque}

Afonso Albuquerque holds a PhD from the Rio de Janeiro Federal University (UFRJ). He is professor at the Post-Graduate Program in Communication, Fluminense Federal University (PPGCOM-UFF). His interests include Political Communication, Journalism, and Comparative Media Studies.

Marcelo Alves dos Santos $J r$

Marcelo Alves dos Santos Jr has a major degree in Journalism from the Federal University of São João del-Rei and is currently a PhD candidate at the Post-Graduate Program in Communication, Fluminense Federal University (PPGCOM-UFF). His research is conducted in the field of internet and politics, focusing on elections, party system, polarization, public opinion and social media. 